\title{
MIR320A wt Allele
}

National Cancer Institute

\section{Source}

National Cancer Institute. MIR320A wt Allele. NCI Thesaurus. Code C82182.

The human MIR320A wild-type allele is located in the vicinity of 8p21.3 and is approximately 81 bases in length. This allele, which encodes MIR320A pre-miRNA, plays a role in the regulation of gene expression. Alteration in the expression of this gene is associated with cholangiocarcinoma, acute myeloid leukemia and sickle cell disease. 